Check for updates

Cite this: RSC Adv., 2018, 8, 37905

Received 23rd August 2018

Accepted 31st October 2018

DOI: $10.1039 / c 8 r a 07060 a$

rsc.li/rsc-advances

\title{
Facile synthesis of indole heterocyclic compounds based micellar nano anti-cancer drugs $\dagger$
}

\author{
Imran Ali, (D)*ab Sofi Danish Mukhtar, ${ }^{a}$ Ming Fa Hsieh, ${ }^{c}$ Zeid A. Alothman ${ }^{\text {d }}$ \\ and Abdulrahman Alwarthan ${ }^{\mathrm{d}}$
}

Facile synthesis of micellar "nano" indole heterocyclic anti-cancer compounds is described. The synthesized compounds (11-23) were characterized by UV-VIS, ${ }^{1} \mathrm{H}$ NMR, FT-IR and mass spectroscopy. The binding energies of DNA-compound adducts varied from -20.08 to $-23.85 \mathrm{~kJ} \mathrm{~mol}^{-1}$, and they were stabilized by hydrophobic interactions and $\mathrm{H}$-bonding. The synthesized compounds enter into minor grooves of DNA during adduct formation. The DNA binding constant of compounds 11-23 was 1.00 to $2.00 \times 10^{5} \mathrm{M}^{-1}$. The drug-loading efficiency and drug-loading content in their micellar forms were recorded. Compounds 11,12, 14 and 19 at a micellar concentration of $670 \mu \mathrm{L} \mathrm{mL}^{-1}$ displayed excellent anticancer activities against the HepG2/C3A line (25-50\%). The potency of nano anticancer drugs was predicted by drug likeness using Lipinski's "rule of five". Taken together, compounds 11-23 could be used to treat cancers.
\end{abstract}

\section{Introduction}

Molecules such as cisplatin, 5-fluorouracil and taxol have been used to treat cancer but cannot cure cancers, especially for late-stage disease. Besides, these molecules show various serious side effects by damaging healthy body cells. ${ }^{1}$ The most notorious problems with these drugs are a narrow therapeutic range, cytotoxicity and poor solubility. ${ }^{2}$ Moreover, no single drug can cure different types of cancers. ${ }^{3,4}$ These challenges can be addressed by developing "nano" anti-cancer drugs because they are cell-specific, targeted drugs that show few side effects. ${ }^{5-15}$ Hence, different research teams, clinicians and regulatory authorities are looking for effective nano anticancer drugs.

Heterocyclic compounds appear to be most effective against various cancers. ${ }^{16,17}$ Around $60 \%$ of the medications used for cancer are based on heterocyclic moieties. ${ }^{18}$ Among the various heterocyclic moieties, nitrogen-based compounds have been found to be effective against different types of cancers. ${ }^{19}$ Indoles (Fig. 1) are heterocyclic moieties with

${ }^{a}$ Department of Chemistry, College of Sciences, Taibah University, Al-Medina Al-Munawara, 41477, Saudi Arabia. E-mail: drimran.chiral@gmail.com; drimran_ali@yahoo.com

${ }^{b}$ Department of Chemistry, Jamia Millia Islamia (Central University), New Delhi110025, India

'Department of Biomedical Engineering, Chung Yuan Christian University, 200, Chung Pei Rd., Chung Li, Taiwan

${ }^{d}$ Department of Chemistry, College of Science, King Saud University, Riyadh 11451, Kingdom of Saudi Arabia

$\dagger$ Electronic supplementary information (ESI) available. See DOI: $10.1039 / \mathrm{c} 8 \mathrm{ra} 07060 \mathrm{a}$ a broad range of pharmacological properties, including antitumor. ${ }^{20-23}$ Ahmad et al. ${ }^{24}$ reported apoptosis of human cancer cells using indoles. Indoles have been shown to inhibit the proliferation of human cancer cells. ${ }^{25-27}$ Liao et al. ${ }^{28}$ showed that 2-aryl-3-substituted indoles derivatives were active against the breast cancer cell line MCF-7. Treatment with indoles or their derivatives [e.g., I3C(indole-3-carbinol) and DIM (3,3'diindolylmethane)] can result in the apoptosis of breast, ${ }^{29}$ squamous cell carcinoma, ${ }^{30}$ cholangiocarcinoma, ${ }^{31}$ colon $^{32}$ and ovarian tumor cells. ${ }^{33}$ These indolic heterocycles may be decisive anti-cancer agents for several human cancer cell lines. ${ }^{34}$ Csipo et al. ${ }^{35}$ studied the chemosensitization of indole moieties such as I3C and DIM.

Here, we synthesized a heterocyclic series ingrained with indolic moieties, followed by purification and characterization by column chromatography and spectroscopy. DNA binding studies of synthesized molecules were carried out and DNA binding constants calculated. The synthesized molecules were loaded onto micellar "nanocarriers". The activities of the developed nano anticancer drugs were tested on HepG2(C3A) cell lines. Finally, Lipinski's rule was applied to these synthesized compounds to ascertain if they could become anti-cancer drugs.

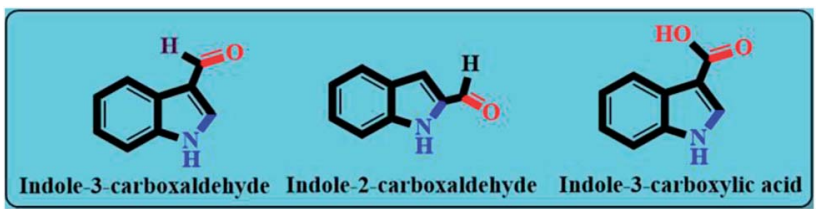

Fig. 1 Chemical structures of indole-3-carboxaldehyde, indole-2carboxaldehyde and indole-3-carboxylic acid. 


\section{Experimental}

\subsection{Chemicals and reagents}

Sulfuric acid, potassium hydroxide and formaldehyde of AR grade were purchased from Merck (Mumbai, India), as were LiChrosolv® chloroform, hexane and methanol. Indole-3carboxaldehyde, 4-nitroaniline, 4-fluroaniline, 4-bromoaniline, 4chloroaniline, 4-methylaniline, 2-methylaniline and Ct-DNA were purchased from Spectrochem (Mumbai, India). Aluminum silica gel (60 F254) thin-layer plates were procured from Merck (Darmstadt, Germany). The human cancer cell line HepG2/C3A was from National Taiwan University (Taipei City, Taiwan). MTT [3-(4,5dimethylthiazol-2-yl)-2,5-diphenyl tetrazolium bromide] was obtained from Sigma-Aldrich (Saint Louis, MO, USA). Dulbecco's modified Eagle's medium (DMEM) and antimycotics/antibiotics were purchased from Gibco (Billings, MT, USA). Fetal bovine serum (FBS) was obtained from HyClone (Jülich, Germany). Poly( $\varepsilon$ caprolactone)-block poly(ethylene glycol)-poly( $\varepsilon$-caprolactone), abbreviated as PCL-PEG-PCL (nanocarrier) was obtained from Reinste Nano Ventures (New Delhi, India).

\subsection{Instrumentation}

Fourier transform infrared (FT-IR) spectroscopy was carried out using a RXIFT spectrometer (LR 64912C; PerkinElmer,
Waltham, MA, USA). A UV/VIS spectrometer (T80) from PG Instruments (Lutterworth, UK) was employed. A DPX300 300 MHz system (Bruker, Billerica, MA, USA) was used for NMR studies. A micrOTOF-Q II ${ }^{\mathrm{TM}}$ ESI-Qq-TOF mass spectrometer (10262; Bruker) was also used. Melting points were determined using a system developed by Veego Instruments (REC-22038; Mumbai). Deionized water was collected by a Milli-Q (Millipore; Bedford, MA, USA) water-purification system. Synthesized compounds were purified by flash chromatography using a pump (MP-200), UV detector and computer with CHEETAH software.

\subsection{Wet chemistry}

2.3.1 Syntheses of the condensates of indole (3-10). A clear solution of indole-3-carboxaldehyde (1) (10 mM) was prepared in ethanol/dioxane $(2: 1, \mathrm{v} / \mathrm{v})$. Equimolar amounts of the corresponding aniline derivatives (2) [4-nitroaniline, 4-fluroaniline, 4-bromoaniline, 4-chloroaniline, 4-methylaniline, 2methylaniline] were added separately. These were stirred to obtain clear solutions. A few drops of concentrated $\mathrm{H}_{2} \mathrm{SO}_{4}$ were added with constant heating under reflux for 4-6 h. The reaction was determined by thin-layer chromatography (TLC) using $\mathrm{MeOH}: \mathrm{CHCl}_{3}(1: 3, \mathrm{v} / \mathrm{v})$ solvent. Solid products started to precipitate and were filtered off after completion of the reaction.<smiles>N[Y]1ccccc1N</smiles>

(1) $\mathrm{H}$

(2)

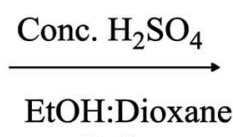

$(2: 1)$<smiles>[R]1ccc(/N=C\c2c[nH]c3ccccc23)cc1</smiles>

(3-10)

$3=\mathrm{R}=4-\mathrm{NO}_{2}, \mathbf{4}=\mathrm{R}=4-\mathrm{Br}, \mathbf{5}=\mathrm{R}=4-\mathrm{F}, \mathbf{6}=\mathrm{R}=2-\mathrm{OMe}$,

$\mathbf{7}=\mathrm{R}=2-\mathrm{Me}, \mathbf{8}=\mathrm{R}=4-\mathrm{OMe}, \mathbf{9}=\mathrm{R}=4-\mathrm{Me}, \mathbf{1 0}=\mathrm{R}=4-\mathrm{Cl}$.<smiles>[R]1ccc(/N=C\c2c[nH]c3ccccc23)cc1</smiles>

$\underset{\text { EtOH:Dioxane }}{\mathrm{HCHO}}$

2) Morpholine<smiles>[R]Oc1ccc(/N=C/c2cn(CN3CCOCC3)c3ccccc23)cc1</smiles>

$11=\mathrm{R}=4-\mathrm{NO}_{2}, 12=\mathrm{R}=4-\mathrm{Br}, 13=\mathrm{R}=4-\mathrm{F}$, $14=\mathrm{R}=2-\mathrm{OMe}, 15=\mathrm{R}=2-\mathrm{Me}, 16=\mathrm{R}=4$ $\mathrm{OMe}, 17=\mathrm{R}=4-\mathrm{Me}, 18=\mathrm{R}=4-\mathrm{Cl}$.<smiles>C1=CC=IC=C1</smiles>

\section{$\frac{\text { 1) } \mathrm{HCHO}}{\text { EtOH:Dioxane }}$ $(2: 1)$}

2) N-methyl piperazine<smiles>[R]c1ccc(/N=C\c2cn(CN3CCN(C)CC3)c3ccccc23)cc1</smiles>

$$
\begin{aligned}
& \mathbf{1 9}=\mathrm{R}=4-\mathrm{NO}_{2}, \mathbf{2 0}=\mathrm{R}=4-\mathrm{F}, \\
& \mathbf{2 1}=\mathrm{R}=2-\mathrm{OMe}, \mathbf{2 2}=\mathrm{R}=4-\mathrm{Me}, \\
& \mathbf{2 3}=\mathrm{R}=4-\mathrm{Cl} .
\end{aligned}
$$


They were re-crystallized in an ethanol and dioxane $(2: 1, \mathrm{v} / \mathrm{v})$ mixture to obtain pure products. The synthesized compounds (3-10) are shown in Scheme 1.

2.3.2 Syntheses $\mathrm{N}$-substituted indoles (11-23). A solution (15 mL) of indole $N$-(1H-indol-3-yl methylene)-4-nitroaniline ${ }^{3}$ (10 $\mathrm{mM})$ was prepared in a mixture of ethanol and dioxane $(2: 1, \mathrm{v} / \mathrm{v})$. Then, formaldehyde $(40 \% ; 1.5 \mathrm{~mL})$ and morpholine $(10 \mathrm{mM} ; 0.087 \mathrm{~mL})$ in ethanol were added to the solution. Then, the mixture was stimulated for 3-4 h and left overnight. The solid was collected by filtration and recrystallized from ethanol and dioxane $(2: 1, \mathrm{v} / \mathrm{v})$ to yield 11. Compounds 12-23 were synthesized by the same procedure used in the preparation of compound 3. Compounds having $Z$-geometry of $\mathrm{C}=\mathrm{N}$ were formed because of the peak in IR spectra (i.e., only $Z /$ cis can show a peak in IR spectra). Also, the synthesized compound was stable in biological conditions. The purity of the synthesized compounds was ascertained by column chromatography and flash chromatography.

2.3.3 Encapsulation of synthesized compounds (11-23) in PCL-PEG-PCL nanocarriers. These compounds (3.0 $\mathrm{mg}$ each) were dissolved in $1.0 \mathrm{~mL}$ of a binary solution of THF : DMSO $(1: 1, \mathrm{v} / \mathrm{v})$, separately, as was $20 \mathrm{mg}$ of the polymer $\left(\mathrm{PCL}_{60^{-}}\right.$ $\left.\mathrm{PEG}_{40}-\mathrm{PCL}_{60}\right)$. The compounds and polymer solutions were mixed in $3.0 \mathrm{~mL}$ of double-distilled water and stirred for $3 \mathrm{~h}$. The resultant samples were placed in dialysis bags (molecular weight $(\mathrm{MW})$ cutoff $=8000)$ and dialyzed for $24 \mathrm{~h}$ to obtain micellar solutions, the formation of which was confirmed by UV-VIS spectrometry by determining $\lambda_{\max }$.

\subsection{Docking studies}

Docking studies were carried out as per standard protocol. ${ }^{36-38}$ Heterocyclic molecules containing nitrogen, oxygen and sulfur atom interact with the major and minor grooves of DNA. ${ }^{39}$ The synthesized compounds contained the same number of nitrogen and sulfur atoms. These heteronuclear compounds tend to interact with DNA, as shown by docking studies theoretically and by DNA binding experimentally. Also, the cancercausing genes (i.e., oncogenes) are also present on DNA. "DNA intercalation" refers to insertion of molecules into DNA bases and cause frameshift mutations. Our synthesized compounds could act as DNA intercalators.

\subsection{DNA binding}

Interactions of compounds 11-23 were studied with Ct-DNA $(\mathrm{pH}$ 7.4) in a solution of deionized water with tris(hydroxymethyl)-amino methane buffer (Tris, $10^{-2} \mathrm{M}$ ). Initially, the concentration of freshly prepared Ct-DNA solution was determined by UV-VIS absorption spectrophotometry at $260 \mathrm{~nm}$ $\left(\varepsilon=6600 \mathrm{M}^{-1} \mathrm{~cm}^{-1}\right.$ ) by knowing its absorbance. ${ }^{40}$ To carry out binding experiments, the absorption spectra of freshly prepared compounds 11-23 at a fixed concentration of $1.6 \times 10^{-4} \mathrm{M}$ were taken separately, and then at different concentrations of DNA $\left(5.15 \times 10^{-5}, 3.0 \times 10^{-5}, 1.00 \times 10^{-5}, 0.9 \times 10^{-5}\right.$ and $0.7 \times$ $\left.10^{-5} \mathrm{M}\right) . \lambda_{\max }$ was recorded and the absorbance of the mixture (i.e., with each different solution of DNA and compounds) was also measured. Experiments were repeated five times. The intrinsic DNA binding constant $\left(K_{\mathrm{b}}\right)$ was resolved using the Benesi-Hildebrand equation as modified by Wolfe et al.:41

$$
[\mathrm{DNA}] /\left(\varepsilon_{\mathrm{a}}-\varepsilon_{\mathrm{f}}\right)=[\mathrm{DNA}] /\left(\varepsilon_{\mathrm{a}}-\varepsilon_{\mathrm{f}}\right)+1 / K\left(\varepsilon_{\mathrm{b}}-\varepsilon_{\mathrm{f}}\right)
$$

where the absorption coefficients $\varepsilon_{\mathrm{a}}, \varepsilon_{\mathrm{f}}$, and $\varepsilon_{\mathrm{b}}$ represent $A_{\mathrm{obs}} /$ [compound], the extinction coefficient for the molecule, and the extinction coefficient for molecule in the fully bound form,

Table 1 Docking parameters of compounds 11-23

\begin{tabular}{|c|c|c|c|c|}
\hline Compound & $\begin{array}{l}\text { Binding energy } \\
\mathrm{KJ} \mathrm{mol}^{-1}\end{array}$ & No. of H-bonds & Residues involved in H-bonding (bond length) & $\begin{array}{l}\text { Residues involved in hydrophobic } \\
\text { interactions }\end{array}$ \\
\hline 11 & -20.50 & 3 & $\begin{array}{l}\text { A: } \mathrm{DT}^{\prime} 8 \mathrm{H}: \mathrm{Unk} 0: \mathrm{O} \text { of nitro group }(3.55) \\
\text { B: } \mathrm{DG}^{\prime} 10 \mathrm{H}: \text { Unk0:N of } \mathrm{C}=\mathrm{N} \text { group }(3.43) \\
\mathrm{C}: \mathrm{DC}^{\prime} 15 \mathrm{H}: \text { Unko: } \mathrm{N} \text { of morpholine group }(3.48)\end{array}$ & Dt8, Dc9, Dg10, Dg14 \& Dc15 \\
\hline 12 & -21.34 & 2 & $\begin{array}{l}\text { A: } \mathrm{DG}^{\prime} 14 \mathrm{H}: \mathrm{Unk} 0: \mathrm{N} \text { of } \mathrm{C}=\mathrm{N} \text { group }(3.40) \\
\text { B: } \mathrm{DG}^{\prime} 10 \mathrm{H}: \mathrm{Unk} 0: \mathrm{O} \text { of nitro group }(3.39)\end{array}$ & Dt8, Dc9, Dg10, Dc13, Dg14, Dc15 \& Dg16 \\
\hline 13 & -22.59 & 2 & $\begin{array}{l}\text { A: DG'14H:Unk0:O of morpholine group }(3.36) \\
\text { B: DG'10H:Unk0:N of } \mathrm{C}=\mathrm{N} \text { group }(3.42)\end{array}$ & Dt8, Dc9, Dg10, Dg14, Dc15 \& Dg16 \\
\hline 14 & -22.59 & 1 & A: DG'10H:Unk0:Nof morpholine group (3.51) & Dt8, Dc9, Dg10, Dc13, Dg14, Dc15 \& Dg16 \\
\hline 15 & -23.85 & 1 & A: DG'10H:Unk0:Nof morpholine group (3.49) & Dt8, Dc9, Dg10, Dg14 \& Dc15 \\
\hline 16 & -20.50 & 2 & $\begin{array}{l}\text { A: DC'13H:Unk0:O of methoxy group (3.39) } \\
\text { B: DG'14H:Unko:O of morpholine group }(3.44)\end{array}$ & Dt8, Dc9, Dg10, Dc13, Dg14, Dc15 \& Dg16 \\
\hline 17 & -20.92 & 1 & A: $\mathrm{DG}^{\prime} 10 \mathrm{H}: U n k 0: \mathrm{N}$ of $\mathrm{C}=\mathrm{N}$ group $(3.32)$ & Dt8, Dc9, Dg10, Dc13, Dg14, Dc15 \& Dg16 \\
\hline 18 & -21.34 & 2 & $\begin{array}{l}\text { A: } \mathrm{DG}^{\prime} 14 \mathrm{H}: \text { Unk } 0: \mathrm{N} \text { of } \mathrm{C}=\mathrm{N} \text { group }(3.43) \\
\text { B: } \mathrm{DG}^{\prime} 10 \mathrm{H}: \text { Unk0:N of indole group }(3.40)\end{array}$ & Dt8, Dc9, Dg10, Dc13, Dg14, Dc15 \& Dg16 \\
\hline 19 & -20.08 & 2 & $\begin{array}{l}\text { A: } \mathrm{DG}^{\prime} 10 \mathrm{H}: \mathrm{Unk} 0: \mathrm{N} \text { of } \mathrm{C}=\mathrm{N} \text { group }(3.42) \\
\mathrm{B}: \mathrm{DC}^{\prime} 13 \mathrm{H}: \text { Unk0:O of nitro group }(3.24)\end{array}$ & Dt8, Dc9, Dg10, Dc13, Dg14 \& Dc15 \\
\hline 20 & -20.92 & 2 & $\begin{array}{l}\text { A: } \mathrm{DG}^{\prime} 10 \mathrm{H}: \text { Unk0:N of } \mathrm{C}=\mathrm{N} \text { group }(3.35) \\
\mathrm{B}: \mathrm{DG}^{\prime} 14 \mathrm{H}: \text { Unk0:N of indole group }(3.46)\end{array}$ & Dt8, Dc9, Dg10, Dc13, Dg14 \& Dc15 \\
\hline 21 & -20.92 & 1 & A: DC'9H:Unk0:N of indole group (3.57) & Dt8, Dc9, Dg10, Dc13, Dg14, Dc15 \& Dg16 \\
\hline 22 & -21.34 & 1 & A: DC'9H:Unk0:N of indole group (3.58) & Dt8, Dc9, Dg10, Dc13, Dg14 \& Dc15 \\
\hline 23 & -20.92 & 2 & $\begin{array}{l}\text { A: } \mathrm{DC}^{\prime} 14 \mathrm{H}: \text { Unk0:N of } \mathrm{C}=\mathrm{N} \text { group }(3.41) \\
\text { B: } \mathrm{DG}^{\prime} 10 \mathrm{H}: \text { Unk0:N of indole group }(3.28)\end{array}$ & Dt8, Dc9, Dg10, Dc13, Dg14 \& Dc15 \\
\hline
\end{tabular}




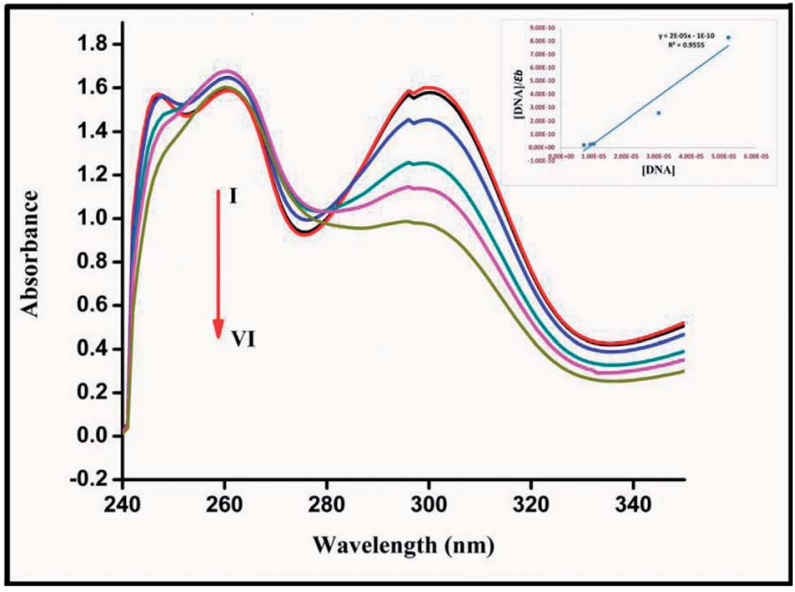

(a)

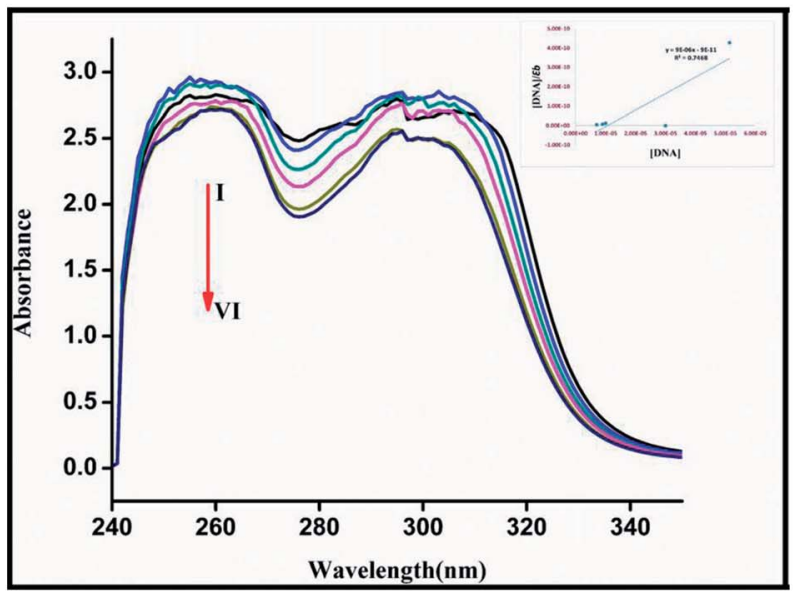

(b)

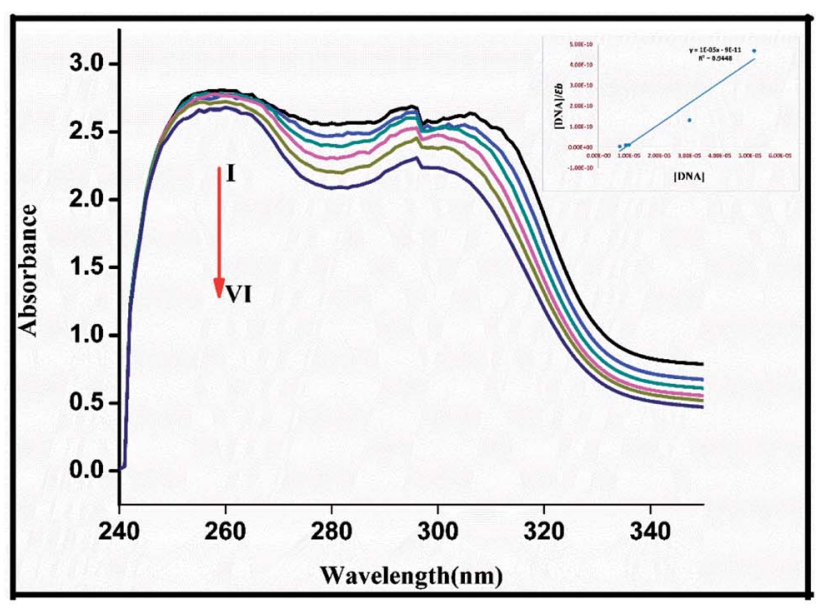

(c)

Fig. 2 (a-c) Absorption spectra of compounds 11, 21 and 23 in the absence and presence of different Ct-DNA concentrations. Arrows indicate the decrease in absorbance upon addition of decreasing concentrations of DNA. Inset: plots of $[D N A] / \varepsilon_{b} v s$. [DNA] for the absorption titration of $\mathrm{Ct}$-DNA with compounds. DNA concentrations are (1) $5.15 \times 10^{-5}$, (2) $3.0 \times 10^{-5}$, (3) $1.00 \times 10^{-5}$, (4) $0.9 \times 10^{-5}$, and (5) $0.7 \times 10^{-5}$. respectively. The $K_{\mathrm{b}}$ for dissimilar compounds was ascertained by division of the slopes and intercepts of the plots of $[\mathrm{DNA}] /\left(\varepsilon_{\mathrm{a}}\right.$ $\left.-\varepsilon_{\mathrm{f}}\right) v s$. [DNA].

\subsection{Determination of drug loading}

2.6.1 Drug-loaded micelles. Synthesized molecules $(0.2$ $\mathrm{mg}$ ) were loaded onto micelles and measured by UV-VIS spectrophotometry. DMF $(4.0 \mathrm{~mL})$ and $\mathrm{H}_{2} \mathrm{O}(0.9 \mathrm{~mL})$ were introduced into $0.1 \mathrm{~mL}$ of a drug-loaded micellar solution. Due to ultrasonic vibration for $10 \mathrm{~min}$, micelles were broken up and the molecules (11-23) dissolved in the solutions. The characteristic absorbance of the molecules was recorded at $320 \mathrm{~nm}$ and compared with a standard curve generated from a solvent mixture of DMF/ $\mathrm{H}_{2} \mathrm{O}$ in $4: 1(\mathrm{v} / \mathrm{v})$ ratio. Two main concepts were utilized to determine molecule loading: drug-loading efficiency (DLE) (also known as entrapment efficiency [EE]), and drugloading content (DLC). DLE is given by: ${ }^{42}$

$$
\text { DLC }=\left(\frac{\text { weight of loaded drug }}{\text { weight of polymer }}\right) \times 100 \%
$$

DLE/EE is given by:

$$
\mathrm{DLE} / \mathrm{EE}=\left(\frac{\text { weight } \text { of loaded drug }}{\text { weight of drug in feed }}\right) \times 100 \%
$$

2.6.2 Anticancer assays. In vitro anticancer profiles of the nano drugs (11-23) were determined reiteratively with a murine microglial cell line (HepG2/C3A) by a cell viability (MTT) assay. ${ }^{43}$ The principle of the MTT assay is to remove succinic acid from the mitochondria of living cells under the action of hydrogenase and cytochrome $\mathrm{C}$. The tetrazolium ring opens to form purple crystals, which are eluted and have an absorbance peak at $570 \mathrm{~nm}$. The experimental method involved four steps. First, HepG2/C3A cells were seeded in 96-well dishes at $1 \times 10_{4} /$ well. Cells were allowed to attach for $24 \mathrm{~h}$ and washed several times with phosphate-buffered saline (PBS) and serum-free medium containing micellar solution-encapsulated drugs. Second, the old medium was removed at the end of incubation time, and fresh water containing $0.5 \mathrm{mg} \mathrm{mL} \mathrm{m}^{-1}$ of MTT added. Third, the medium was cultured for $4 \mathrm{~h}$, the culture medium removed and $100 \mu \mathrm{L}$ of DMSO was added to the ELISA Reader. Crystals were dissolved by shaking for $5 \mathrm{~min}$, and the absorbance at $570 \mathrm{~nm}$ measured. Finally, cell cytotoxicity was calculated using the following equation:

$$
\text { Cell cytotoxicity }=\frac{\operatorname{Abs}(570 \mathrm{~nm}) \text { sample }}{\text { Abs }(570 \mathrm{~nm}) \text { control }} \times 100 \%
$$

\section{Results and discussion}

Finally, 13 compounds (11-23) were synthesized (Scheme 1) and purified by flash chromatography. The melting points of synthesized compounds were recorded. The synthesized compounds were characterized by UV-VIS, FT-IR, mass and NMR spectroscopy. Their structural data are described in ESI. $\dagger$ 
Table 2 Wavelength shifts, \%hypochromism and binding constants of compounds 11-23

\begin{tabular}{|c|c|c|c|c|c|}
\hline Compound & $\lambda_{\max }($ free $)$ & $\begin{array}{l}\lambda_{\max } \\
\text { (bound to DNA) }\end{array}$ & Change & \%hypochromism ${ }^{a}$ & $K_{\mathrm{b}}^{b}\left(\mathrm{M}^{-1}\right)$ \\
\hline 11 & $300 \mathrm{~nm}$ & $260 \mathrm{~nm}$ & 40 & 39.29 & $2.0 \times 10^{5}$ \\
\hline 13 & $261 \mathrm{~nm}$ & $260 \mathrm{~nm}$ & 1 & 0.22 & $1.0 \times 10^{5}$ \\
\hline 14 & $255 \mathrm{~nm}$ & $257 \mathrm{~nm}$ & 2 & 9.11 & $1.125 \times 10^{5}$ \\
\hline 15 & $255 \mathrm{~nm}$ & $255 \mathrm{~nm}$ & 0 & 0.34 & $1.125 \times 10^{5}$ \\
\hline 18 & $262 \mathrm{~nm}$ & $264 \mathrm{~nm}$ & 2 & 4.53 & $1.111 \times 10^{5}$ \\
\hline 19 & $260 \mathrm{~nm}$ & $260 \mathrm{~nm}$ & 0 & 0.46 & $1.0 \times 10^{5}$ \\
\hline 20 & $264 \mathrm{~nm}$ & $258 \mathrm{~nm}$ & 6 & 0.41 & $1.125 \times 10^{5}$ \\
\hline 21 & $260 \mathrm{~nm}$ & $261 \mathrm{~nm}$ & 1 & 4.17 & $1.0 \times 10^{5}$ \\
\hline 22 & $258 \mathrm{~nm}$ & $256 \mathrm{~nm}$ & 2 & 5.89 & $1.25 \times 10^{5}$ \\
\hline 23 & $259 \mathrm{~nm}$ & $260 \mathrm{~nm}$ & 1 & 5.03 & $1.111 \times 10^{5}$ \\
\hline
\end{tabular}

${ }^{a} \%$ hypochromicity $(H \%)=\left[\left(A_{\mathrm{f}}-A_{\mathrm{b}}\right) / A_{\mathrm{f}}\right] \times 100$, where $A_{\mathrm{f}}$ and $A_{\mathrm{b}}$ represent the absorbance of free and bound compounds. ${ }^{b}$ Binding constants.

Table 3 DLC and DLE values of compounds 11-23

\begin{tabular}{lcc}
\hline Compound & DLC & DLE/EE \\
\hline $\mathbf{1 1}$ & $5.42 \%$ & $54.2 \%$ \\
$\mathbf{1 2}$ & $2.44 \%$ & $24.4 \%$ \\
$\mathbf{1 3}$ & $4.52 \%$ & $45.2 \%$ \\
$\mathbf{1 4}$ & $3.54 \%$ & $35.4 \%$ \\
$\mathbf{1 5}$ & $0.58 \%$ & $5.8 \%$ \\
$\mathbf{1 6}$ & $3.30 \%$ & $33.0 \%$ \\
$\mathbf{1 7}$ & $0.33 \%$ & $3.28 \%$ \\
$\mathbf{1 8}$ & $4.10 \%$ & $41.0 \%$ \\
$\mathbf{1 9}$ & $1.44 \%$ & $14.4 \%$ \\
$\mathbf{2 1}$ & $4.87 \%$ & $48.7 \%$ \\
$\mathbf{2 2}$ & $3.53 \%$ & $35.3 \%$ \\
$\mathbf{2 3}$ & $4.79 \%$ & $47.9 \%$ \\
& $3.17 \%$ & $31.7 \%$
\end{tabular}

\subsection{Docking studies}

To study the in silico properties of compounds 11-23 with DNA, theoretical DNA docking studies were carried out. B-DNA is most common form used due to its wide and deep major grooves, narrow and deep minor grooves, and its pattern of base pairing between the two DNA strands. It gives different hydrogen bond donor/acceptor forms in the major and minor grooves, respectively.

The DNA docking of compounds 11-23 was done with DNA dodecamers d(CGCGAATTCGCG)2 having a (PDB ID: 1BNA) file. The DNA docking results are shown in Fig. SI1-5 (ESI) $\dagger$ and Table 1. Almost all compounds adjusted themselves in a cocrystalized ligand-like appearance in the vicinities of DNA. The binding affinities of compounds 11-23 followed the order $15>14 \approx 13>18 \approx 22 \approx 12>23 \approx 17 \approx 20 \approx 21>16 \approx$ $11>19$.

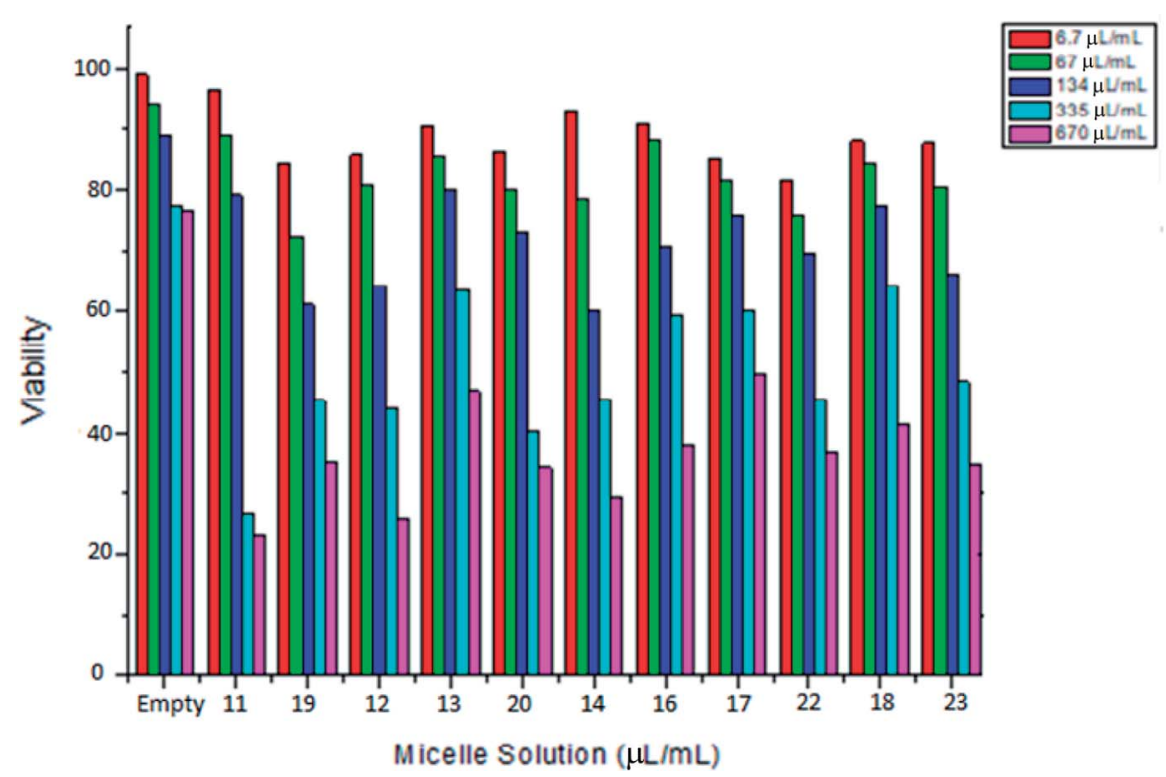

Fig. 3 Percentage viabilities of HepG2/C3A cells upon treatment with compounds $11-23$ at micellar concentrations of $6.7,67,134,335$ and 670 $\mu \mathrm{L} \mathrm{mL}^{-1}$ 


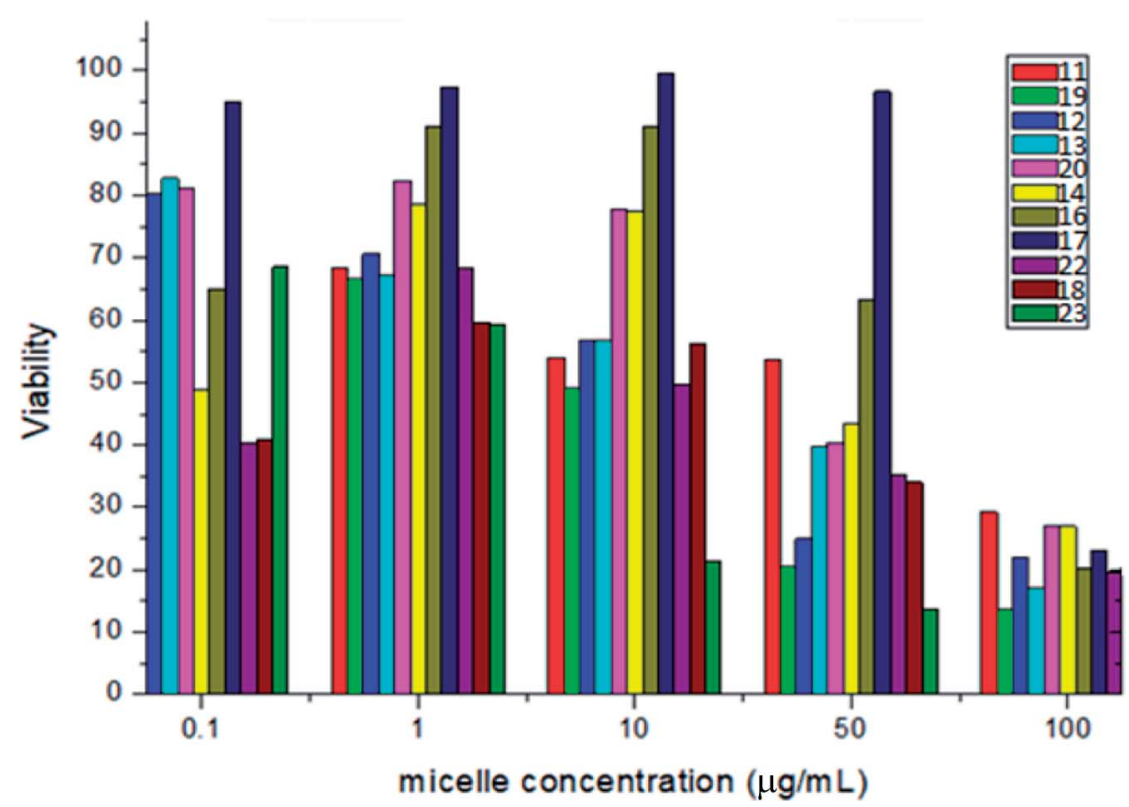

Fig. 4 Percentage viabilities of HepG2/C3A cells upon treatment with compounds $11-23$ at micellar concentrations of $0.1,1.0,10,50$ and $100 \mu \mathrm{g}$ $\mathrm{mL}^{-1}$

Table $4 \quad I_{50}$ values of drugs in micelles in the HepG2/C3A line

\begin{tabular}{lc}
\hline Compounds & $\mathrm{IC}_{50}(\mu \mathrm{g} \mathrm{mL})$ \\
\hline 11 & 3.85 \\
12 & 2.03 \\
13 & 3.30 \\
14 & 1.91 \\
16 & 5.28 \\
17 & 3.27 \\
18 & 3.66 \\
19 & 1.63 \\
20 & 4.29 \\
22 & 18.7 \\
23 & 7.28 \\
\end{tabular}

The number of hydrophobic interactions and H-bonds of compounds 11-23 with DNA are given in Table 1 . The hydrogen bonds formed in the DNA-compound adducts were one for $\mathbf{1 4}$, $15,17,21$ and 22, two for 12, 13, 16, 18, 19 and 20, and three for 11 compounds, respectively. During the interaction with DNA, compounds 11-23 adjusted themselves so that their substituted indole, morpholine and $N$-methylpiperazine rings were within the minor grooves of DNA mostly, whereas $Z$-geometry $\mathrm{C}=\mathrm{N}$ moieties attached to benzene rings were mainly in the major grooves of DNA. Also, 1-3 H-bonds were formed by this spatial orientation. The residues of DNA involved in H-bonding were guanine, adenine, cytosine and thymine bases (DG'14H, DG'10H, DC'9H, DC'13H, DC'15H, DT'8H) with the amine group of the indole ring, morpholine and $\mathrm{N}$-methylpiperazine rings. Also, cyano and methoxy groups were attached to benzene rings. One hydrogen bond was attached to guanine and cytosine bases. This twisting of rings might have been because of the GCrich region with a large positive potential responsible for molecular attraction, ${ }^{44}$ and more repulsion from phosphate groups in the backbone. Also, twisting can lead to more hydrogen bonding. It can be seen in Fig. SI1† that, during the molecular interaction of compound $\mathbf{1 1}$ with DNA, it favored the minor grooves of DNA with $-20.50 \mathrm{~kJ} \mathrm{~mol}^{-1}$ of binding energy. Compound $\mathbf{1 1}$ formed three hydrogen bonds with the residues (thymine, guanine and cytosine) of DNA with bond lengths of 3.55, 3.43 and $3.48 \AA$, respectively. With regard to hydrophobic interactions, the nitrogen-containing nucleobases Dt8, Dc9, Dg10, Dg14 and Dc15 were involved. Similarly, compound 19 preferred the minor grooves of DNA and formed two hydrogen bonds with the residues of DNA with a binding affinity of $-20.08 \mathrm{~kJ} \mathrm{~mol}^{-1}$ (ESI $\dagger$ ). The residues involved in hydrogen bonding were DG'10H and DC'13H. Besides these interactions, compound 19 (ESI $\dagger$ ) also interacted with the nitrogencontaining nucleobases of DNA hydrophobically in a twodimensional network. The residues involved in these hydrophobic interactions were Dt8, Dc9, Dg10, Dc13, Dg14 and Dc15. It is not useful to discuss the details of docking studies for all compounds as all the compounds interacted with DNA in a similar fashion.

\subsection{DNA binding}

Interactive study of newly synthesized heterocyclic moieties with DNA is crucial for estimation of their anticancer activity, and to shed light on a viable mechanism of their action. Hence, DNA binding is considered to be the most essential experimental step to measure the activity of anticancer drugs because most anticancer drugs target DNA specifically. ${ }^{45}$ In general, there are two modes of binding of a drug with DNA: noncovalent or covalent. In covalent binding, a labile ligand is replaced with a nitrogen atom of a DNA base, such as N7 of guanine. In non-covalent binding, there are "electrostatic", 
Table 5 Lipinski's 'rule-of-five' data for compounds 11-23

\begin{tabular}{|c|c|c|c|c|c|c|c|}
\hline Compounds & Mol. wt & No. of HBA & No. of HBD & Mol $\log P$ & $\begin{array}{l}\text { Mol } \log S \\
{[\log (\text { moles per L })] /\left(\mathrm{mg} \mathrm{L}^{-1}\right)}\end{array}$ & $\begin{array}{l}\text { Mol PSA } \\
\left(\mathrm{A}^{2}\right)\end{array}$ & $\operatorname{Mol} \operatorname{vol}\left(\mathrm{A}^{3}\right)$ \\
\hline 11 & 365.16 & 5 & 1 & 2.74 & $-5.78(0.61)$ & 61.69 & 352.50 \\
\hline 12 & 397.08 & 3 & 0 & 4.00 & $-6.43(0.15)$ & 23.43 & 344.16 \\
\hline 13 & 337.16 & 3 & 0 & 3.42 & $-5.80(0.53)$ & 23.43 & 328.22 \\
\hline 14 & 349.18 & 4 & 0 & 3.12 & $-5.24(2.02)$ & 30.37 & 354.43 \\
\hline 15 & 333.18 & 3 & 0 & 3.43 & $-5.71(0.65)$ & 22.73 & 342.94 \\
\hline 16 & 349.18 & 4 & 0 & 3.24 & $-5.54(1.00)$ & 30.98 & 354.14 \\
\hline 17 & 333.18 & 3 & 0 & 3.55 & $-5.74(0.61)$ & 23.43 & 343.24 \\
\hline 18 & 353.13 & 3 & 0 & 3.86 & $-6.24(0.20)$ & 23.43 & 339.50 \\
\hline 19 & 378.19 & 5 & 1 & 2.80 & $-5.39(1.56)$ & 57.26 & 377.68 \\
\hline 20 & 350.19 & 3 & 0 & 3.47 & $-5.41(1.37)$ & 19.00 & 353.40 \\
\hline 21 & 362.21 & 4 & 0 & 3.17 & $-4.84(5.18)$ & 25.93 & 379.61 \\
\hline 22 & 346.22 & 3 & 0 & 3.60 & $-5.35(1.56)$ & 19.00 & 368.42 \\
\hline 23 & 366.16 & 3 & 0 & 3.92 & $-5.85(0.52)$ & 19.00 & 364.68 \\
\hline
\end{tabular}

"groove" and "intercalative" types of interactions. Bathochromic and hypochromic shifts revealed the intercalative binding of compounds with DNA. Intercalation enhanced strong stacking interactions between aromatic chromophores and the base pairs of DNA. ${ }^{46}$ Also, the electrostatic binding of a compound with DNA decreased the $\pi \rightarrow \pi^{*}$ transition energy because the $\pi^{*}$ orbital of the ligand interacted with DNA base pairs. This led to a lower hypochromic effect with no or negligible bathochromic shift. ${ }^{47}$ However, covalent bonding led to bathochromism and hyperchromism due to breaking of the DNA structure when a compound interacted with DNA covalently. A compound coordinating with DNA through the N7 position of guanine was indicated by a bathochromic shift. Binding with the outside groove of DNA had a minor or no effect and, rarely, some hyperchromism was shown by groove binding in the UV-VIS spectrum ${ }^{\mathbf{4 8 , 4 9}}$

The purity of DNA in the Ct-DNA stock solution was shown by $A_{260} / A_{280} \geq 1.80$, which indicated a sufficiently DNA proteinfree nature. ${ }^{50}$ With the addition of DNA, slight band shifting was observed at 200-350 $\mathrm{nm}$. The concentration of the stock solution of DNA was determined experimentally by utilizing $\varepsilon=$ $6600 \mathrm{M}^{-1} \mathrm{~cm}^{-1}$ at $260 \mathrm{~nm}$. Additional solutions of DNA (3.0, 1.0, 0.9 and $\left.0.7 \times 10^{-4} \mathrm{M}\right)$ were made from a stock solution $(5.15 \times$ $\left.10^{-5} \mathrm{M}\right)$. The concentration of the compounds was fixed at $1.6 \times$ $10^{-4} \mathrm{M}$. With each different concentration of DNA solution, absorption spectra were recorded.

The DNA binding spectra of the most effective compounds, 11, 21 and 23, are shown in Fig. 2a-c, respectively. Changes such as hypochromism (low to moderate) and slight shifting of bands indicated the interaction of compounds with DNA bands via electrostatic mode due to a decrease of the $\pi \rightarrow \pi^{*}$ transition energy because the $\pi^{*}$ orbital of the intercalated ligand coupled with the orbital of the base pairs. Graphs of compounds 20 and 17 (ESI $\dagger$ ) showed that hyperchromism was because these compounds were covalently bonded with DNA, which was due to breakage of the DNA structure.

Graphs of compounds 12, 13, 15, 16, 18 and 19 (ESI $\dagger$ ) showed no change in UV-VIS spectra when the different DNA concentrations were added to solutions of the compounds. This confirmed the outer-groove binding of DNA with the compound with low hyperchromism and negligible bathochromism. The $K_{\mathrm{b}}$ was calculated for compounds 11-23 and ranged from 1.0 to $2.0 \times 10^{5} \mathrm{M}^{-1}$, thereby confirming that the synthesized compounds interacted strongly with DNA. Using Microsoft Excel $^{\mathrm{TM}}$, regression analysis was carried out for DNA binding studies. The correlation coefficient $\left(R^{2}\right)$ was found to be $0.7468-$ $0.9555 \%$. The order of $K_{\mathrm{b}}$ for compounds 11-23 was almost identical. Finally, we summarized that nearly all the synthesized heterocyclic compounds interacted with Ct-DNA through minor grooves, as noted by other scholars..$^{51-53}$ Overall, the order of binding of differently substituted compounds with DNA was nitro $>$ halogen $>$ methoxy $>$ methyl groups. The binding constants, \% hypochromism and wavelength shifts of compounds 11-23 are given in Table 2. Hence, DNA binding studies were comparable with DNA docking studies. Therefore, compounds 11-23 acted as DNA-binding agents.

\subsection{DLC and DLE of drugs encapsulated in micelles}

Drug-loaded micelles were prepared by dialysis. All the drugs loaded in micelles showed good results of DLC and DLE (Table 3 ). DLC ranged from $0.33 \%$ to $5.42 \%$. Higher DLC was shown by compound 11 and lower by compound 17. DLE ranged from $3.28 \%$ to $54.2 \%$. Compound 11 showed highest DLE and the lowest was shown by compound 17 . DLE was relatively good but showing no clear pattern. During dialysis, no precipitate or aggregate was observed. DLC and EE data predicted drug loading into nanocarriers. Also, the encapsulation experiment done with PCL-PEG-PCL nanocarrier showed its efficiency as a nanodrug. Micelle formation is shown in ESI. $\dagger$

\subsection{Anticancer profiles of nano drugs}

The prepared nano drugs were tested for anticancer activities in terms of \% viability on the HepG2/C3A line. The viability of HepG2C3A cells after exposure to compounds 11-23 at varying micellar concentrations $\left(6.7,67,134,335\right.$, and $\left.670 \mu \mathrm{L} \mathrm{mL}^{-1}\right)$ are given in Fig. 3 and 4. Fig. 3 reveals that the indole derivatives 11-23 at a micellar concentration of $670 \mu \mathrm{L} \mathrm{mL}{ }^{-1}$ led to viabilities of HepG2/C3A cells of 25, 35, 28, 48, 32, 30, 39, 50, 40, 


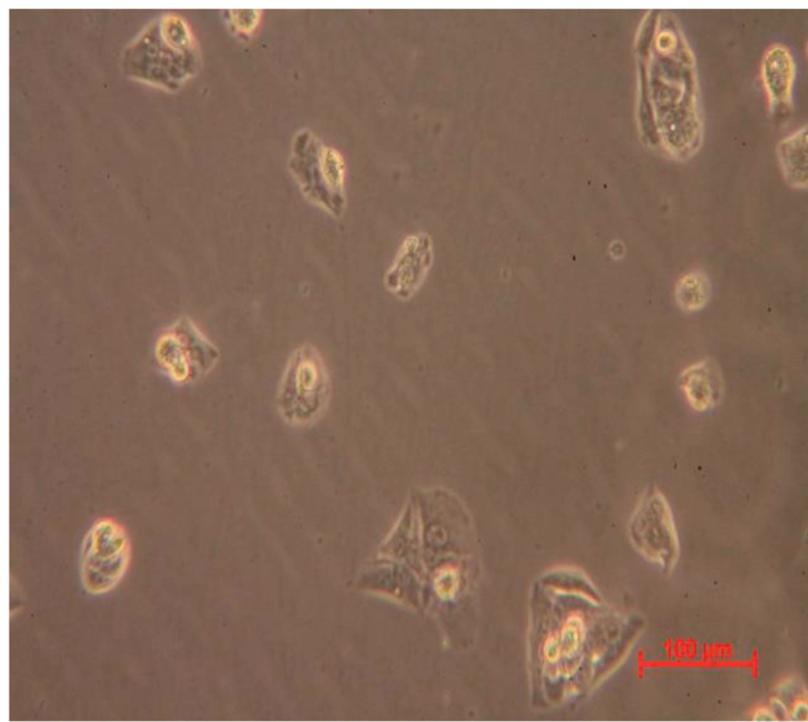

(a)

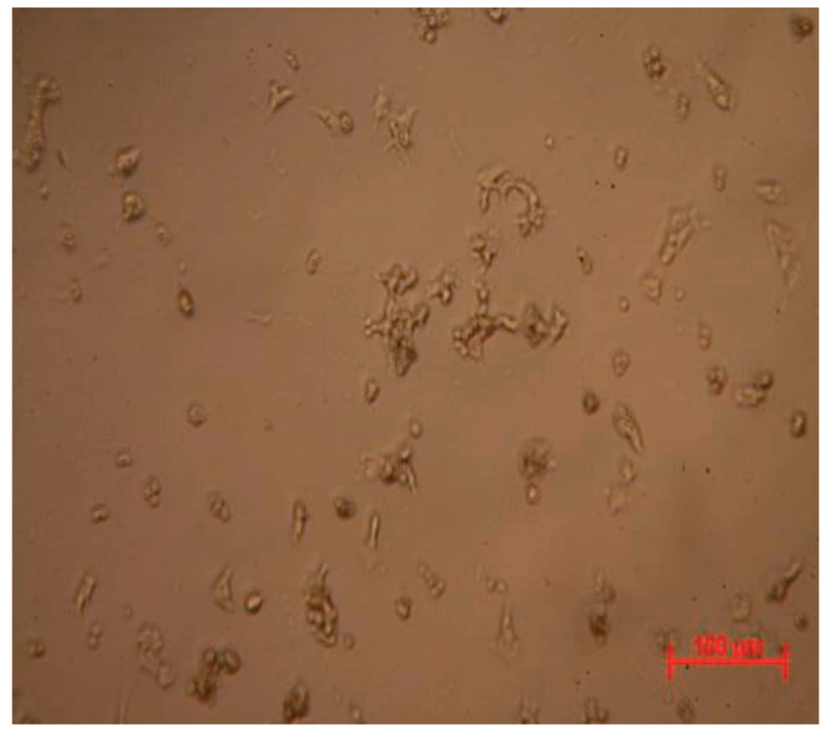

(b)

Fig. 5 Morphology of HepG2 cells (a) before treatment and (b) after treatment with nano drugs.

45 and $38 \%$. Thus, HepG2/C3A cells displayed low viability upon treatment with heterocyclic moieties 11, 12, 14, 20 and 19, which indicated the good anticancer potential of these synthesized heterocyclic compounds. Fig. 4 shows all the indole moiety derivatives (11-23) caused low viability of HepG2/C3A cells at a micellar concentration of $100 \mu \mathrm{g} \mathrm{mL} \mathrm{m}^{-1}$. Also, compound 23 showed low viability at micellar concentrations of 10 and $50 \mu \mathrm{g} \mathrm{mL}{ }^{-1}$. Therefore, these synthesized compounds interacted differently and had different mechanisms with different cell targets. Also, the half-maximal inhibitory concentration $\left(\mathrm{IC}_{50}\right)$ was calculated for the micelles formed for compounds 11-23 (Table 4). Compounds 12, 14, 17 and 19 showed $\mathrm{IC}_{50}$ values in the range $1.63-18.70 \mu \mathrm{g} \mathrm{mL}^{-1}$ at low concentrations. Half of the cells were dead and compound 22 showed a low $\mathrm{IC}_{50}$. Morphologies of HepG2 cells before and after treatment with nanodrugs are shown in Fig. $5 \mathrm{a}$ and b: the nano drugs were effective because all cells died after treatment (Fig. 5b).

\subsection{Drug likeness}

In general, the time required to synthesize promising compounds and utilize them is long because their toxicity, pharmacokinetic properties and effects on metabolism must be tested. This leads to considerable burdens on the research-anddevelopment budget of a pharmaceutical company. A number of scientists and researchers are involved to find answers of the above questions. Lipinski's "rule of five" can be used to identify some of the important properties of compounds considered theoretically to be drugs. That is, molecules must have good membrane permeability, $\mathrm{MW}<400, \log P<5$, number of $\mathrm{H}$ bond donors $<5$ and number of $\mathrm{H}$-bond acceptors $<10$. For analyses of small drug-like molecules, a filter of $\log D>0$ and $<3$ increases the chances of a compound displaying good intestinal permeability. Moreover, a compound that has $>10$ hydrogen bond acceptors and 5 hydrogen-bond donors shows poor permeation. Therefore, this rule was applied to compounds 1123 synthesized according to the procedure described by Veber et al. ${ }^{54}$ As seen in Table 5, compounds 11-23 followed Lipinski's rule of five.

\section{Conclusions}

Thirteen compounds (11-23) were synthesized with good yield and loaded onto micellar nanocarriers. DNA-binding studies indicated that compound-DNA adducts were stabilized mainly by electrostatic attractions, van der Waals forces and hydrogen bonding. The minor grooves of DNA were the areas through which the synthesized compounds interacted with DNA. Hypochromism indicated that the synthesized compounds bound with DNA through electrostatic attraction and intercalations $K_{\mathrm{b}}$ values $\left(1.0\right.$ to $\left.2.0 \times 10^{5} \mathrm{M}^{-1}\right)$ indicated the strong binding affinities of compounds 11-23. Good percentages of DLC and DLE were achieved. Cell viability was $25-50 \%$ at $670 \mu \mathrm{L}$ $\mathrm{mL}^{-1}$, which indicated excellent anticancer activities. $\mathrm{IC}_{50}$ values were 1.63-18.70 $\mu \mathrm{g} \mathrm{mL} \mathrm{m}^{-1}$. Compounds 11-23 followed Lipinski's rule of five. Compounds 11-23 could be used to treat cancers.

\section{Conflicts of interest}

There is no conflict of interest for this manuscript.

\section{Acknowledgements}

The authors extend their appreciation to the International Scientific Partnership Program ISPP at King Saud University for funding this research work (ISPP \# 0037). 


\section{References}

1 K. Saleem, W. A. Wani, A. Haque, A. Malhotra and I. Ali, Nanodrugs: magic bullets in cancer chemotherapy, Top. Anti-Cancer Res., 2013, 58, 437-494.

2 M. Pulkkinen, J. Pikkarainen, T. Wirth, T. Tarvainen, V. Haapa-aho, H. Korhonen and K. Järvinen, Three-step tumor targeting of paclitaxel using biotinylated PLA-PEG nanoparticles and avidin-biotin technology: formulation development and in vitro anticancer activity, Eur. J. Pharm. Biopharm., 2008, 70, 66-74.

3 M. Kidwai, R. Venktaramanan, R. Mohan and P. Sapra, Cancer chemotherapy and heterocyclic compounds, Curr. Med. Chem., 2002, 9, 1209-1228.

4 I. Ali, K. Kumerer and H. Y. Aboul-Enein, Mechanistic principles in chiral separations using liquid chromatography and capillary electrophoresis, Chromatographia, 2006, 63, 295-307.

5 I. Ali, Nano anti-cancer drugs: pros and cons and future perspectives, Curr. Cancer Drug Targets, 2011, 11, 131-134.

6 I. Ali, S. D. Mukhtar, M. N. Lone, H. S. Ali and H. Y. AboulEnein, Recent advances in mesoporous silica and gold based nanovectors in anticancer drug delivery system, Curr. Org. Chem., 2017, 21, 2400-2415.

7 I. Ali, M. N. Lone, M. Suhail, S. D. Mukhtar and L. Asnin, Advances in nanocarriers for anticancer drugs delivery, Curr. Med. Chem., 2016, 23, 2159-2187.

8 I. Ali, K. Saleem, H. Y. Aboul-Enein and A. Rather, Social Aspects of Cancer Genesis, Cancer Ther., 2011, 8, 6-14.

9 I. Ali, Nano drugs: Novel agents for cancer chemo-therapy, Curr. Cancer Drug Targets, 2011, 11, 130.

10 I. Ali, K. Saleem, D. Wesselinova and A. Haque, Synthesis, DNA binding, hemolytic, and anti-cancer assays of curcumin I-based ligands and their ruthenium (III) complexes, Med. Chem. Res., 2013, 22, 1386-1398.

11 I. Ali and H. Y. Aboul-Enein, Enantioseparation of some clinically used drugs by HPLC using cellulose Tris (3,5dichlorophenylcarbamate) chiral stationary phase, Biomed. Chromatogr., 2003, 17, 113-117.

12 I. Ali, V. K. Gupta, H. Y. Aboul-Enein and B. sharma, Role of racemization in optically active drugs development, Chirality, 2007, 19, 453-463.

13 H. Y. Aboul-Enein and I. Ali, Determination of tadalafil in pharmaceutical preparation by HPLC using monolithic silica column, Talanta, 2005, 65, 276-280.

14 I. Ali, K. Saleem, I. Hussain and H. Y. Aboul-Enein, Polysaccharides chiral stationary phases in liquid chromatography, Sep. Purif. Rev., 2009, 38, 97-147.

15 I. Ali, Z. A. Alothman and M. M. Sanagi, Green synthesis of iron nano-impregnated adsorbent for fast removal of fluoride from water, J. Mol. Liq., 2015, 211, 457-465.

16 I. Ali, M. N. Lone, Z. A. Al-Othman, A. Al-Warthan and M. M. Sanagi, Heterocyclic scaffolds: centrality in anticancer drug development, Curr. Drug Targets, 2015, 16, 711-734.
17 H. Y. Aboul-Enein and I. Ali, Comparative study of the enantiomeric resolution of chiral antifungal drugs econazole, miconazole and sulconazole by HPLC on various cellulose chiral columns in normal phase mode, $J$. Pharm. Biomed. Anal., 2002, 27, 441-446.

18 W. W. Paudler and R. M. Sheets, Recent Developments in Naphthyridine Chemistry, Adv. Heterocycl. Chem., 1983, 33, 147-184.

19 S. M. Gomha, N. A. Kheder, M. R. Abdelaziz and Y. N. Mabkhot, A Novel Series of Thiazoles and 1, 3, 4Thiadiazoles Bearing Thiazole Moiety as Anticancer Agents: Synthesis, Spectral Studies, Biological Evaluation and Structure Activity relationship, (2016).

20 I. Ali and H. Y. Aboul-Enein, Enantioseparation of some clinically used drugs by HPLC using cellulose Tris (3, 5-dichlorophenylcarbamate) chiral stationary phase, Biomed. Chromatogr., 2003, 17, 113-117.

21 N. C. Hung, J. M. Lhoste, F. Lavelle, M. C. Bissery and E. Bisagni, Synthesis and antitumor activity of 1[[(dialkylamino) alkyl] amino]-4-methyl-5H-pyrido [4, 3-b] benzo [e]-and-benzo [g]) indoles. A new class of antineoplastic agents, J. Med. Chem., 1990, 33, 1519-1528.

22 H. D. Jain, C. Zhang, S. Zhou, H. Zhou, J. Ma, X. Liu and K. S. Smith, Synthesis and structure-activity relationship studies on tryprostatin A, an inhibitor of breast cancer resistance protein, Bioorg. Med. Chem., 2008, 16, 4626-4651.

23 J. T. Hartmann and L. Kanz, Sunitinib and periodic hair depigmentation due to temporary c-KIT inhibition, Arch. Dermatol., 2008, 144, 1525-1526.

24 A. Ahmad, W. A. Sakr and K. M. Rahman, Mechanisms and therapeutic implications of cell death induction by indole compounds, Cancers, 2011, 3, 2955-2974.

25 H. Y. Aboul-Enein and I. Ali, HPLC enantiomeric resolution of nebivolol on normal and reversed amylose based chiral phases, Pharmazie, 2001, 56, 214-216.

26 I. Ali., H. Y. Aboul-Enein and M. M. Sanagi, Advances in chiral separations by non-aqueous capillary electrophoresis in pharmaceutical and biomedical analysis, Electrophoresis, 2014, 35, 926-936.

27 F. H. Sarkar, Y. Li, Z. Wang and D. Kong, Cellular signaling perturbation by natural products, Cell. Signalling, 2009, 21, 1541-1547.

28 S. Y. Liao, L. Qian, T. F. Miao, H. L. Lu and K. C. Zheng, MFA and docking studies of 2-phenylindole derivatives with anticancer activity, Eur. J. Med. Chem., 2009, 44, 2822-2827.

29 C. Hong, H. A. Kim, G. L. Firestone and L. F. Bjeldanes, 3, 3'Diindolylmethane (DIM) induces a G1 cell cycle arrest in human breast cancer cells that is accompanied by Sp1mediated activation of p21WAF1/CIP1 expression, Carcinogenesis, 2002, 23, 1297-1305.

30 Y. Chen, J. Xu, N. Jhala, P. Pawar, Z. B. Zhu, L. Ma and J. M. McDonald, Fas-mediated apoptosis in cholangiocarcinoma cells is enhanced by $3,3^{\prime}$ diindolylmethane through inhibition of AKT signaling and FLICE-like inhibitory protein, Am. J. Pathol., 2006, 169, 1833-1842. 
31 G. Pappa, M. Lichtenberg, R. Iori, J. Barillari, H. Bartsch and C. Gerhäuser, Comparison of growth inhibition profiles and mechanisms of apoptosis induction in human colon cancer cell lines by isothiocyanates and indoles from Brassicaceae, Mutat. Res., Fundam. Mol. Mech. Mutagen., 2006, 599, 76-87.

32 E. J. Kim, S. Y. Park, H. K. Shin, D. Y. Kwon, Y. J. Surh and J. H. Y. Park, Activation of caspase-8 contributes to 3, 3'diindolylmethane-induced apoptosis in colon cancer cells, J. Nutr., 2007, 137, 31-36.

33 M. Abdelrahim, K. Newman, K. Vanderlaag, I. Samudio and S. Safe, 3, 3'-diindolylmethane (DIM) and its derivatives induce apoptosis in pancreatic cancer cells through endoplasmic reticulum stress-dependent upregulation of DR5, Carcinogenesis, 2005, 27, 717-728.

34 L. J. Yuan, J. B. Liu and X. G. Xiao, Biooxidation of indole and characteristics of the responsible enzymes, Afr. J. Biotechnol., 2011, 10, 19855-19863.

35 I. Csipo, A. H. Montel, J. A. Hobbs, P. A. Morse and Z. Brahmi, Effect of Fast and Fas - target cells on the ability of NK cells to repeatedly fragment DNA and trigger lysis via the Fas lytic pathway, Apoptosis, 1998, 3, 105-114.

36 G. M. Morris, D. S. Goodsell, R. S. Halliday, R. Huey, W. E. Hart, R. K. Belew and A. J. Olson, Automated docking using a Lamarckian genetic algorithm and an empirical binding free energy function, J. Comput. Chem., 1998, 19, 1639-1662.

37 S. Shafia, M. M. Alam, N. Mulakayala, C. Mulakayala, G. Vanaja, A. M. Kalle, R. Pallu and M. S. Alam, Synthesis of novel 2-mercapto benzothiazole, Eur. J. Med. Chem., 2012, 49, 324-333.

38 M. F. Sanner, Python: a programming language for software integration and development, J. Mol. Graphics Modell., 1999, 17, 57-61.

39 G. J. Atwell, J. Y. Fan, K. Tan and W. A. Denny, DNA-Directed Alkylating Agents. 7. Synthesis, DNA Interaction, and Antitumor Activity of Bis(hydroxymethyl)- and Bis(carbamate)-Substituted Pyrrolizines and Imidazoles, $J$. Med. Chem., 1998, 41, 4744-4754.

40 M. E. Reichmann, S. A. Rice, C. A. Thomas and P. Doty, A further examination of the molecular weight and size of desoxypentose nucleic acid, J. Am. Chem. Soc., 1954, 76, 3047-3053.

41 A. Wolfe, G. H. Shimer Jr and T. Meehan, Polycyclic aromatic hydrocarbons physically intercalate into duplex regions of denatured DNA, Biochemistry, 1987, 26, 6392-6396.

42 X. Huang, Y. Xiao and M. Lang, Micelles/sodium-alginate composite gel beads: A new matrix for oral drug delivery of indomethacin, Carbohydr. Polym., 2012, 87, 790-798.
43 T. Mosmann, Rapid colorimetric assay for cellular growth and survival: application to proliferation and cytotoxicity assays, J. Immunol. Methods, 1983, 65, 55-63.

$44 \mathrm{~S}$. Neidle, DNA minor-groove recognition by small molecules, Nat. Prod. Rep., 2001, 189, 291-309.

45 I. Ali, W. A. Wani, K. Saleem and M. F. Hsieh, Anticancer metallodrugs of glutamic acid sulphonamides: in silico, DNA binding, hemolysis and anticancer studies, RSC Adv., 2014, 4, 29629-29641.

46 I. Ali, A. Haque, K. Saleem and M. F. Hsieh, Curcumin-I Knoevenagel's condensates and their Schiff's bases as anticancer agents: synthesis, pharmacological and simulation studies, Bioorg. Med. Chem., 2013, 21, 3808-3820.

47 R. Indumathy, M. Kanthimathi, T. Weyhermuller and B. U. Nair, Cobalt complexes of terpyridine ligands: crystal structure and nuclease activity, Polyhedron, 2008, 27, 34433450 .

48 P. Zhao, L. C. Xu, J. W. Huang, J. Liu, H. C. Yu, K. C. Zheng and L. N. Ji, Experimental and DFT studies on DNA binding and photocleavage of two cationic porphyrins: effects of the introduction of a carboxyphenyl into pyridinium porphyrin, Spectrochim. Acta, Part A, 2008, 71, 1216-1223.

49 H. Guo, C. Cai, H. Gong and X. Chen, Multi-spectroscopic method study the interaction of anti-inflammatory drug ketoprofen and calf thymus DNA and its analytical application, Spectrochem Acta Part A: Mol and Biomol Spectros, 2011, 79, 92-96.

50 G. Pratviel, J. Bernadou and B. Meunier, DNA and RNA cleavage by metal complexes, Adv. Inorg. Chem., 1998, 45, 251-312.

51 I. Ali, A. Haque, K. Saleem and M. F. Hsieh, Bioorganic \& Medicinal Chemistry Curcumin-I Knoevenagel's condensates and their Schiff's bases as anticancer agents: synthesis, pharmacological and simulation studies, Bioorg. Med. Chem., 2013, 21, 3808-3820.

52 N. Perin, R. Nhili, M. Cindrić, B. Bertoša, D. Vušak, I. MartinKleiner and M. Hranjec, Amino substituted benzimidazo [1, 2-a] quinolines: antiproliferative potency, 3D QSAR study and DNA binding properties, Eur. J. Med. Chem., 2016, 122, 530-545.

53 A. Kung, T. Pieper, R. Wissiack, E. Rosenberg and B. K. Keppler, Hydrolysis of the tumor inhibiting ruthenium (III) complexes HIm trans-[RuCl4 (im) 2] and HInd trans- [RuCl4 (ind) 2] investigated by means of HPCE and HPLC-MS, J. Biol. Inorg Chem., 2001, 6, 292-299.

54 D. F. Veber, S. R. Johnson, H. Y. Cheng, B. R. Smith, K. W. Ward and K. D. Kopple, Molecular properties that influence the oral bioavailability of drug candidates, $J$. Med. Chem., 2002, 45, 2615-2623. 